\title{
SEDIMENT QUALITY AND POSSIBLE USES OF DREDGED MATERIALS: THE RIA DE AVEIRO LAGOON MOUTH AREA (PORTUGAL)
}

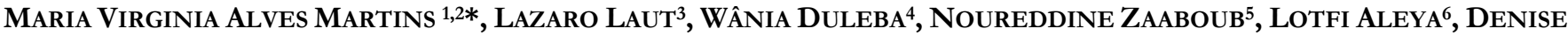

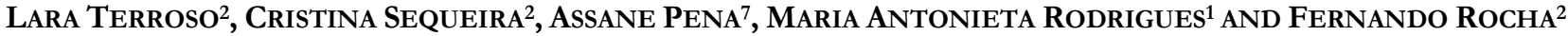

1 Universidade do Estado do Rio de Janeiro, Faculdade de Geologia, Departamento de Estratigrafia e Paleontologia. Av. São Francisco Xavier, 524, sala 2020A, Maracanã. 20550-013 Rio de Janeiro, RJ, Brazil. virginia.martins@ua.pt, tutucauerj@gmail.com

2 Universidade de Aveiro, Dpto. Geociências, GeoBioTec, CESAM, Campus de Santiago, 3810-193, Aveiro, Portugal. laraterroso@ua.pt, csequeira@ua.pt, tavares.rocha@ua.pt

3 Universidade Federal do Estado do Rio de Janeiro (UNIRIO), Laboratório de Micropaleontologia - LABMICRO, Av. Pasteur 458, sala 500, Urca, Rio de Janeiro, RJ, Brazil, CEP 22290-240. lazarolaut@hotmail.com

4 Escola de Artes, Ciências e Humanidades, Universidade de São Paulo, 03828-000 São Paulo - SP, Brasil. wduleba@usp.br 5 Institut National des Sciences et Technologies de la Mer Salammbô, Tunisie. nouri_zaaboub@yahoo.fr

6 Laboratoire de Chrono-Environnement, UMR CNRS 6249, Besançon cedex, France. lotfi.aleya@univ-fcomte.fr

7 Universidade Pedagógica - Moçambique, Departamento de Ciências da Terra e Ambiente. Rua D. Francisco de Almeida $2^{\circ}$ Bairro, Ponta-Gêa, 737/ 751 - Beira - Moçambique - Caixa-postal: 2025. assanepena@ua.pt

* CORRESPONDING AUTHOR, virginia.martins@ua.pt

Received on 9 August 2017

Received in revised form on 17 August 2017

Accepted on 18 August 2017

Editor: Fabriżio Frontalini, Università degli Studi di Urbino "Carlo Bo", Urbino, Italy
SCREENED BY

$\checkmark$ iThenticate
Citation:

Martins, M.V.A., Laut, L., Duleba, W., Zaaboub, N., Aleya, L., Terroso, D.L., Sequeira, C., Pena, A., Rodrigues, M.A., Rocha, F., 2017. Sediment quality and possible uses of dredged materials: the Ria de Aveiro lagoon mouth area (Portugal). Journal of Sedimentary Environments, 2 (2): 149166.

\section{Abstract}

Dredging is a common and important activity to maintain or improve/extend navigable depths in many ports and harbours. Dredging sometimes occur in areas where the sediments are contaminated material and is subject to consent and licensing according to the national regulations. This work shows the general pattern of distribution of potentially toxic elements (PTEs), such as As, Cd, Co, Cr, $\mathrm{Cu}, \mathrm{Ni}, \mathrm{Pb}$ and $\mathrm{Zn}$, in surface sediments of the Ria de Aveiro lagoon mouth area (Portugal). The work is based on textural, mineralogical and geochemical analysis of 137 surface sediment (first centimetre) samples. The Pollution Load Index (PLI) was used to evaluate the overall enrichment of these elements and the enrichment factor (EF) was determined to assess the degree of anthropogenic input of

PTEs. Portuguese Ministerial Order n. ${ }^{\circ} 1450 / 2007$ was used as reference to classify dredging and elimination or application of dredging materials. Results evidence that the study area, which is highly anthropized, the concentration of PTEs is largely controlled by the hydrodynamics. The PLI index values show the highest enrichment of metals in the western side of Mira Channel entrance. The EF values indicate that eighty-three stations have significant enrichment of metals particularly $\mathrm{Pb}$ and $\mathrm{Cr}$ being the significant enrichment by $\mathrm{Cr}$ much more common and by $\mathrm{Pb}$ punctually. According to the Portuguese regulation most of the sites can be classified as clean dredged material (Class 1), sixteen sites as dredged material with trace contamination (Class 2) that may be immersed in the aquatic environment 
taking into account the characteristics of the receiving environment and its legitimate use; and one station (29) as slightly contaminated dredged material (Class 3) that may be used for embankments or in the case of soaking requires a thorough study of the place of deposition and subsequent

\section{Introduction}

Transitional environments are coastal zones with hydrodynamic characteristics and special and complex sedimentary dynamics establishing a connection between land and sea where diverse forces interact (Pye and Allen, 2000; Prandle, 2009). In these zones, frequently influenced by man are constructed ports, harbours, marinas and shipping channels (Prumm and Iglesias, 2016). Sediments are essential, integral and dynamic elements of these areas (e.g. Jouanneau and Latouche, 1981; Ojeda et al., 1995; Wang and Andutta, 2013).

These materials are originated by the weathering of rocks and soils, and can be transported in suspension or as a bottom load during transportation by rivers and tidal currents at transitional and coastal areas, or by wind (Aguiar et al., 2007; Brils, 2008). They are deposited and accumulated in low hydrodynamic areas (Vital and Stattegger, 2000) reducing the depth of the channels and making difficult or preventing navigation (van Maren and Cronin, 2015).

Dredging activities are fundamental and unavoidable in port and estuarine zones to maintain the operation of channels, rivers and ports and to allow the access of regular shipping lines and large vessels (van Maren and Cronin, 2015). Dredging is material taken from or displaced from the bed of the water bodies having in its composition the predominance of mineral particles, ranging from coarse sand to fine, silt and clay, and other materials called waste and tailings (Castro and Almeida, 2012).

The dredging activities have as their first objective to allow the navigability of a stretch of river, estuary and facilitate port activity (Verfaillie et al., 2005; Coelho et al., 2011). The resulting sediments are used, with or without prior evaluation based on scientific studies, in a number of scenarios, including erosion control, aquaculture, agriculture, beach feeding, and stabilization of the coastline, as raw material for the production of aggregates or other products of construction (Marine Board, 1985; Greene, 2005; McLusky and Elliott, 2004; Sheehan et al., 2008, 2010; Siham et al., 2008). The extraction of aggregates may correspond to the removal of sediments from a river, estuary and other water bodies, either in the bottom or in the margins, for the monitoring. In addition, sediments have an important ecological value.

Keywords: Contamination. Trace metals. Enrichment factor. Harbours management. Dredging Regulation.

purpose of marketing these materials, for example for the construction industry (Paiva, 2011; Silva, 2011).

Dredged sediments have been identified as an alternative income to reduce the demand for traditionally exploited natural resources, such as quarries and sand terraces in plains (Shields et al., 2005). Factors conditioning the exploitation of these resources (superficial aggregates) make the use of coastal and marine bottom sediments as a possibility to solve this problem (Cronin, 2009). But the sediments volume has been declining along the coastline of many countries (Park, 2001; Cai et al., 2009).

As sediments can be used as sources of raw materials and to solve several kinds of problems such as coastal erosion (Brils, 2008), they have an increased socioeconomic value. Although dredged sediments are considered to be a promising product and the European Union's directive is looking for environmentally sustainable solutions, most of these materials are dumped at sea, with only a small proportion (2 to 15\%) being beneficially used (Velosa and Cachim, 2011). On the other hand, during dredging it is possible that hazardous chemicals associated with sediments are released into the aquatic environment, causing harmful environmental impacts to aquatic systems (MEMG, 2003; Nicholson et al., 2010). It is estimated that in Portugal, in the total of dredged materials, about $5 \%$ are low contaminated and 1\% are contaminated (Paixão, 2004).

The Portuguese coastline has a considerable length, with an extension of $950 \mathrm{~km}$, presenting alternation of cliffs and caps and stretches of sand with altitude just above the sea level (Ferreira, 2000; Veloso-Gomes et al., 2007; Schmidt et al., 2012). The Portuguese coastline is marked by a climate of intense sea hydrodynamics and the generalized mean sea level rise, and therefore susceptible to the risk of progressive advance of the coastline towards the mainland (Dias et al., 2000; Veloso-Gomes et al., 2007). Coastal erosion is observed in large sections of the Portuguese coast, about one-third is affected by erosion (Veloso-Gomes et al., 2007; Schmidt and Mourato, 2015). 
The deterioration of sediment caused by the anthropic emission of chemicals directly into the water has occurred since the beginning of the industrial revolution (Begy et al., 2016; Barcellos et al., 2017). During the last decades, significant amounts of pollutants are received at these areas and most of them adsorbed by sediment (Chapman and Wang, 2001). Among the several pollutants, trace metals adsorbed by sediments are of particular concern due to their mobility and toxicity in the aquatic ecosystem (Pan and Wang, 2012; Zaaboub et al., 2015, 2016).

The sediments may include different geochemical substrates, some of which have the ability to retain and concentrate trace elements, such as sulphides and iron oxides and manganese hydroxides (Martins et al., 2010, 2015, 2016; Zaaboub et al., 2015, 2016). These materials have high specific surface and high cation exchange capacity. The fundamental characteristic of these materials is that they are thermodynamically unstable, being constituted by amorphous or little crystalline substances (Lima et al., 2001). In addition, to indicating hydrodynamics of the system and benthic environmental conditions, sediments are also important factors in controlling the natural and / or anthropic distribution of chemical elements (Aguiar et al., 2007; Cruz et al., 2013).

Along with its high socioeconomic value, the sediments are the basis for supporting aquatic life (habitats) and providing nutrients for estuarine and marine living food chains. The assessment of sediment quality in harbour areas submitted to dredging operations has been each more a concern of the scientific community, public authorities and the population in general (Pethick, 2002; SedNet 2004, 2006). In addition, dredging operation affects the natural conditions of life (Poiner and Kennedy, 1984). Thus, dredged material dumping is one of the most important human activities to be considered in coastal zone management (Harrington and Smith, 2013; Marmin et al., 2014).

The Ria de Aveiro Lagoon mouth has a multi-functional port that plays a crucial role in serving a wide range of industries in its hinterland, as well as the agricultural and construction sectors (Fig.1). The Port of Aveiro has a huge socio-economic and environmental value for Portugal and for the entire Iberian Peninsula and Europe, since it is used for the traffic of many essential products and materials, being also used as an important area of leisure. It is frequently intervened to improve the engineering structures and regularly and systematically dredged for deepening of berths and navigation channels for access by larger vessels and to maintain the access to channels and manoeuvring and anchorage basins (Plecha et al., 2010, 2012).
The main objective of this work is to analyse the general pattern of distribution of potentially toxic elements (PTEs) concentrations in surface sediments and possible mechanisms of control in the Ria de Aveiro Lagoon mouth (Fig. 1). Surface sediments are also characterized in terms of possible applications if eventually are dredged, according to the Portuguese regulation.

\section{Material and methods}

\subsection{Sampling and laboratorial analyses}

This work analyses sedimentological data of 137 grab samples of sediments collected in 2006/2007 in Ria de Aveiro lagoon mouth (Fig. 1, appendix 1). The sedimentary samples were collected with an adapted Petit Ponnar sampler, with two openings to retrieve surface samples. The analysed stations were georeferenced with GPS (Global Positioning System) and the water depth was measured using the boat sonar. The uppermost first centimetre of sediment was considered for textural, mineralogical and geochemical analysis.

Samples were oven dried at about $45^{\circ} \mathrm{C}$. A homogenized portion of dry sediment sample (of about $250 \mathrm{~g}$ ) was used for grain-size analysis. The fine fraction was separated from the coarser one by wet sieving with distilled water, using a 63 $\mu \mathrm{m}$ mesh screen. The dry fraction $>63 \mu \mathrm{m}$ was sieved through a series of sieves of $125 \mu \mathrm{m}, 250 \mu \mathrm{m}, 500 \mu \mathrm{m}, 1000$ $\mu \mathrm{m}$ and $2000 \mu \mathrm{m}$. Percentage of each sediment fraction was determined. The sediment mean grain size (SMGS) was evaluated based on Folk and Ward (1957).

Total organic carbon (TOC) was determined by loss-onignition in each sample based on the procedure described by Oliver et al. (2001). The TOC values were reported as percentages of dry weight.

The mineralogical and geochemical analyses were carried out in the fine sediment fraction $(<63 \mu \mathrm{m})$. The mineralogical analysis was performed by X-ray diffraction (XRD) techniques, using the Philips PW1130/90 and X'Pert PW3040/60 and $\mathrm{Cu} \mathrm{K} \alpha$ radiation. The scans were performed between $2^{\circ}$ and $40^{\circ} 2 \theta$ (in non-oriented powder). The mineralogical semiquantification was performed according to the methodology described by Martins et al. (2007).

Geochemical analysis was performed in fine fraction by ICP-MS after complete digestion of sediment with four acids $\left(\mathrm{HClO}_{4}, \mathrm{HNO}_{3}, \mathrm{HF}\right.$, and $\left.\mathrm{HCl}\right)$ in ACME Analytical Laboratories (Canada). The concentrations of As, Cd, Co, $\mathrm{Cr}, \mathrm{Cu}, \mathrm{Ni}, \mathrm{Sr}, \mathrm{Pb}$ and $\mathrm{Zn}$ were analysed in this work. 


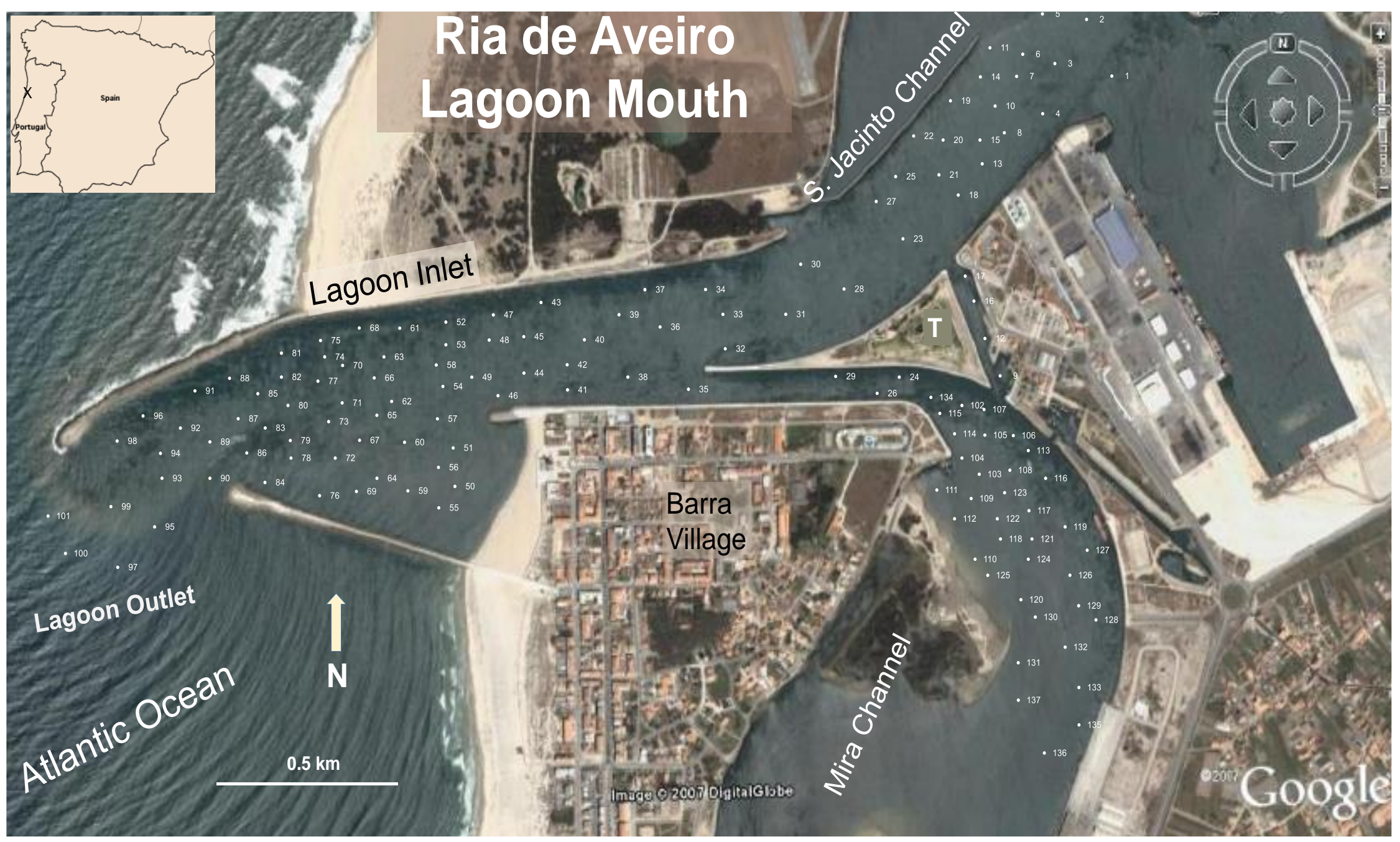

Fig. 1. The study area and samples location at Ria de Aveiro Lagoon mouth (image adapted from Google Earth). T - triangle separator of currents. 


\subsection{Sediment pollution indices}

The Pollution Load Index (PLI), defined by Tomlinson et al. (1980), was used to estimate the overall enrichment of metals of the samples. The PLI is based on concentration factors (CF). A CF is calculated as the ratio between the sediment metal content at a given sampling station and the natural concentration levels for the measured metals, which reflects the metal enrichment in the sediment at that site (Soares et al., 1990).

The PLI of the place, as developed by Tomlinson et al (1980), is determined as follows: $\mathrm{PLI}=\mathrm{n} \sqrt{ }(\mathrm{CF} 1 \mathrm{xCF} 2 \mathrm{xCF} 3 \mathrm{x} \ldots \mathrm{xCFn}), \quad$ where, $\quad \mathrm{CF}=$ contamination factor ( $\mathrm{CF}=\mathrm{C}$ metal / $\mathrm{C}$ background value); $\mathrm{n}=$ number of metals; $\mathrm{C}$ metal $=$ metal concentration in polluted sediments and; $\mathrm{C}$ Background value $=$ background value of that metal. Accordingly, if the PLI value $>1$, the local is polluted, whereas $<1$ indicates no pollution (Harikumar et al., 2009).

Some authors use the world average concentration of trace elements reported for shale (Turekian and Wedepohl, 1961) as the background values. As sediment grain size is quite variable in the study area, we used as background values, the metals concentrations of station 3 , because it had lowest concentrations of $\mathrm{As}, \mathrm{Cd}, \mathrm{Co}, \mathrm{Cr}, \mathrm{Cu}, \mathrm{Ni}, \mathrm{Pb}$ and $\mathrm{Zn}$ and since the baseline values of these elements for the study area were not yet established (Martins et al., 2011). We used the PLI values as indicators of relative metal enrichment and not as a means of determining the degree of pollution of the analysed sites, since the results of this index depends on also of the chosen baseline of PTEs.

To assess the sediment quality and the degree of anthropogenic input, the metal enrichment factor (EF) was also used (Sutherland et al., 2000; Liu et al., 2003; Abrahim and Parker, 2008). The EF compares the ratio of the concentration of one element from the studied sample $v s$. the concentration of a reference element in the same sample, used for normalization, with the same ratio calculated at a reference site, which is considered uncontaminated (station 3 , in this case), using the following equation: $\mathrm{EF}=[(\mathrm{Cx} / \mathrm{Cref})] \mathrm{Sample} /[(\mathrm{Cx} / \mathrm{Cref})]$ Background, where $\mathrm{Cx}$ is the concentration of the element of interest $\left(\mathrm{mg} \mathrm{kg}^{-1}\right)$ and Cref is the concentration of the reference element $\left(\mathrm{mg} \mathrm{kg}^{-1}\right)$ for normalization. The element used for normalization in the estimation of EF was scandium (Sc), which has mostly a lithological origin.

The significance of the EF values according to Sutherland et al. (2000) includes the following ranges: $<2$ deficiency to minimal enrichment; 2-5 - moderate enrichment; 5-20 - significant enrichment; 20-40 - very high enrichment and; $>40$ - extremely high enrichment.

\subsection{Statistical analysis}

Pearson correlations of (textural, mineralogical and geochemical data) were determined after being transformed by $\log (x+1)$ with Statistica 12 software. These data and software were also used in Principal Components Analysis to assess the relationship between data distribution. The maps were performed with the Surfer software 14 (datum WGS84).

\section{Results}

\subsection{Water depth and sediment grain size}

The stations depth ranged from about $1 \mathrm{~m}$ (station 111, located on the west side of the Mira Channel) and to $30 \mathrm{~m}$ (station 90 located at the lagoon inlet, near the south jetty, Appendix 1). In general, the stations with depth less than about $20 \mathrm{~m}$ were concentrated in the Mira Channel, in the connection between this channel to the São Jacinto Channel and in the lagoon inlet (Fig. 1). Also, four stations $(1,4,5,7)$ with depths between $13.0 \mathrm{~m}$ and $14.5 \mathrm{~m}$, were located at the beginning of São Jacinto Channel. The depths between $20 \mathrm{~m}$ and $30 \mathrm{~m}$ are mainly distributed along the main waterway of the Ria de Aveiro mouth (São Jacinto Channel and lagoon inlet).

The SMGS varied between $20 \mu \mathrm{m}$ and $3660 \mu \mathrm{m}$ (mean $610.8 \mu \mathrm{m}$; Appendix 1). The map of distribution of this variable is presented in Fig. 2a. It shows that in general the coarsest sediments were found in S. Jacinto Channel and in the lagoon inlet.

The most predominant and widely distributed type of sediment in the study area (Appendix 1) was the medium sand (with SMGS varying between $254.0 \mu \mathrm{m}$ and 494.0 $\mu \mathrm{m})$. Very fine gravel, very coarse sand and coarse sand (with SMGS varying between $510.9 \mu \mathrm{m}$ and $3660.2 \mu \mathrm{m}$ ) were found along the main channels of the lagoon mouth, at S. Jacinto Channel and the lagoon inlet. The finest lithologies (coarse silt, very coarse silt, very fine sand and fine sand, with SMGS $<249.8 \mu \mathrm{m}$ ) were concentrated in the Mira Channel and close to the south jetty of the lagoon inlet.

\subsection{Mineralogical and geochemical results}

The main minerals that composed the sediment were: quartz $(<91.5 \%$; mean $2.31 \%)$; phyllosilicates $<50.5 \%$; mean $7.31 \%)$; plagioclase $(<42.2 \%$; mean $4.31 \%)$; K-feldspars $(<38.1 \%$; mean $3.3 \%)$; calcite $(<10.6 \% ; 5.3 \%)$ and dolomite $(<6.1 \%$; mean $6.3 \%)$ (Appendix 1). 

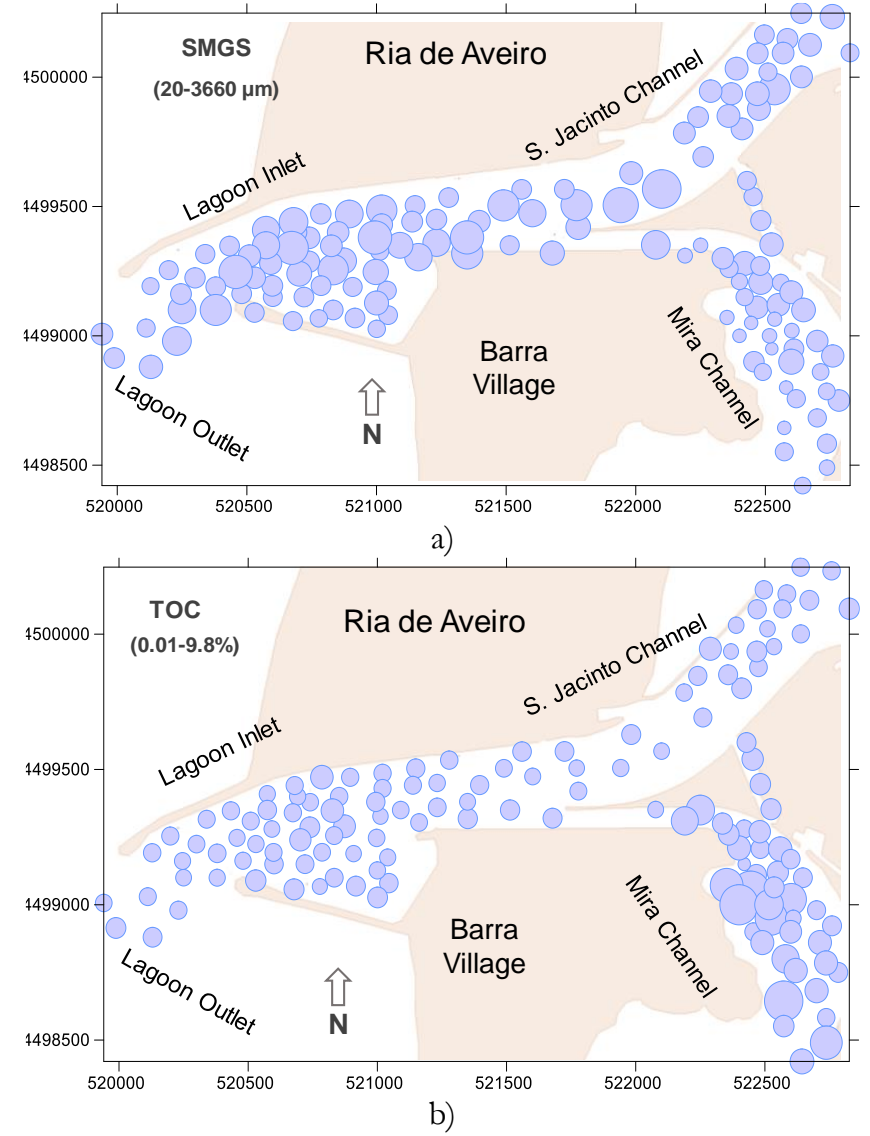

Fig. 2. Pattern of distribution of: a) sediment mean grain size (SMGS; $\mu \mathrm{m}$ ) and, b) TOC (\%) values in Ria de Aveiro mouth.

Concentrations of TOC varied between $0.01-9.8 \%$ (mean $1.3 \%)$ and for the analysed trace metals were as follows: As $0.3-24.0 \mathrm{mg} \mathrm{kg}^{-1}$ (mean $4.0 \mathrm{mg} \mathrm{kg}{ }^{-1}$ ); Cd $0.03-1.0 \mathrm{mg} \mathrm{kg}^{-1}$ (mean $0.1 \mathrm{mg} \mathrm{kg}^{-1}$ ); Co 0.03-8.6 $\mathrm{mg} \mathrm{kg}^{-1}$ (mean $1.3 \mathrm{mg} \mathrm{kg}^{-1}$ ); Cr 0.03-53.7 $\mathrm{mg} \mathrm{kg}^{-1}$ (mean $8.3 \mathrm{mg} \mathrm{kg}^{-1}$ ); Cu 0.03-22.5 mg kg${ }^{1}$ (mean $3.4 \mathrm{mg} \mathrm{kg}^{-1}$ ); Ni $0.03-23.8 \mathrm{mg} \mathrm{kg}^{-1}$ (mean $3.3 \mathrm{mg} \mathrm{kg}$ 1); $\mathrm{Pb} 7.1-151.7 \mathrm{mg} \mathrm{kg}^{-1}$ (mean $24.5 \mathrm{mg} \mathrm{kg}^{-1}$ ); Sc $0.03-8 \mathrm{mg}$ $\mathrm{kg}^{-1}$ (mean $1.5 \mathrm{mg} \mathrm{kg}^{-1}$ ) and; Zn 2.0-134.0 $\mathrm{mg} \mathrm{kg}^{-1}$ (mean 20.4 $\mathrm{mg} \mathrm{kg}-1)$.

Maps of distribution of these variables show that the highest concentrations were reached for TOC (Fig. 2 b) and trace elements such as $\mathrm{As}, \mathrm{Cd}, \mathrm{Co}, \mathrm{Cr}, \mathrm{Cu}, \mathrm{Ni}$ and $\mathrm{Zn}$ (Fig. 3 $\mathrm{a}-\mathrm{g}$ ) in Mira Channel. Concentrations of $\mathrm{Pb}$ followed a different pattern of distribution (Fig. $3 \mathrm{~h}$ ). The highest concentrations of this element were found in few stations located in S. Jacinto Channel, in the lagoon inlet and in a narrow channel lateral to the triangle separator of currents (Fig. 1).

The PLI showed values ranging from 0.4 to 25.6 (Fig. 4a and Appendix 1). The highest PLI values were observed in stations of Mira Channel. Concentrations of PTEs in stations with highest overall concentrations of PTEs $(>50$ $\mathrm{mg} \mathrm{kg}^{-1}$ ) were plotted in Fig. 4b. This graph confirms the described pattern except for $\mathrm{Pb}$. Concentrations of this element increased in isolated stations (such as $29,43,28,42$, $128,72,14,44,50,54$ and 17 , by decreasing order of concentrations). This relationship is exemplified in the pie charts of Fig. 4c, for selected sites, where each trace element reached the highest concentration.

The EF values of As, Cd, Co, Cr, Cu, $\mathrm{Ni}$ and $\mathrm{Pb}$ is presented in Appendix 1 and mapped in Fig. 5 (a-h). The mapped results evidence punctual increases of the EF values in few stations of the study area. The $\mathrm{EF}$ for $\mathrm{Cd}$ and Co were low (>3), for As, $\mathrm{Ni}$ and $\mathrm{Zn}$ varied between 10.0-16.7 and reached the highest values for $\mathrm{Pb}$ (69.9), $\mathrm{Cr}$ (83.3) and $\mathrm{Cu}$ (114.3). Cobalt had a quit homogenous distribution in the study area. For the other PTEs the highest values of EF were punctual or found in few stations.

\subsection{Statistical results}

Correlations between the analysed variables are presented in Table 1. Trace elements and PLI have in general significant positive correlations with TOC, phyllosilicates, calcite, dolomite and plagioclase and negative one with depth and SMGS. Some exceptions (no significant correlations) are observed between: $\mathrm{Pb}$, depth and dolomite; between $\mathrm{Cd}$ and plagioclase. TOC has significant negative correlations with depth and SMGS. The SMGS is significantly and positively correlated with quartz and negatively with plagioclase and phyllosilicates. Depth also has significant negative correlations with plagioclase, dolomite and phyllosilicates.

The results of the PCA, of Factor 1 against Factor 2 (Fig. $6)$, which accounts for most of data variability (61\%), confirm the correlations observed in Table 1. It evidences that metals, but $\mathrm{Pb}$ not so strongly, tend to occur in fine grained sediments, as they are negatively correlated with Factor 1 and SMGS. These metals tend to occur in association with TOC, phyllosilicates and plagioclase. The SMGS is related to depth and to some extent with quartz.

\section{Discussion}

In the deepest areas of Ria de Aveiro lagoon mouth, S. Jacinto Channel and the lagoon inlet, coarse sediments grain size tends to occur due to the prevalence of energetic tidal currents. According to Vaz et al. (2009) currents velocities can be stronger than $2 \mathrm{~m} / \mathrm{s}$ in these areas. The velocity of the currents controls, to some extent, the geochemical and mineralogical composition of the sediments in the lagoon mouth, as indicated by statistical results. 

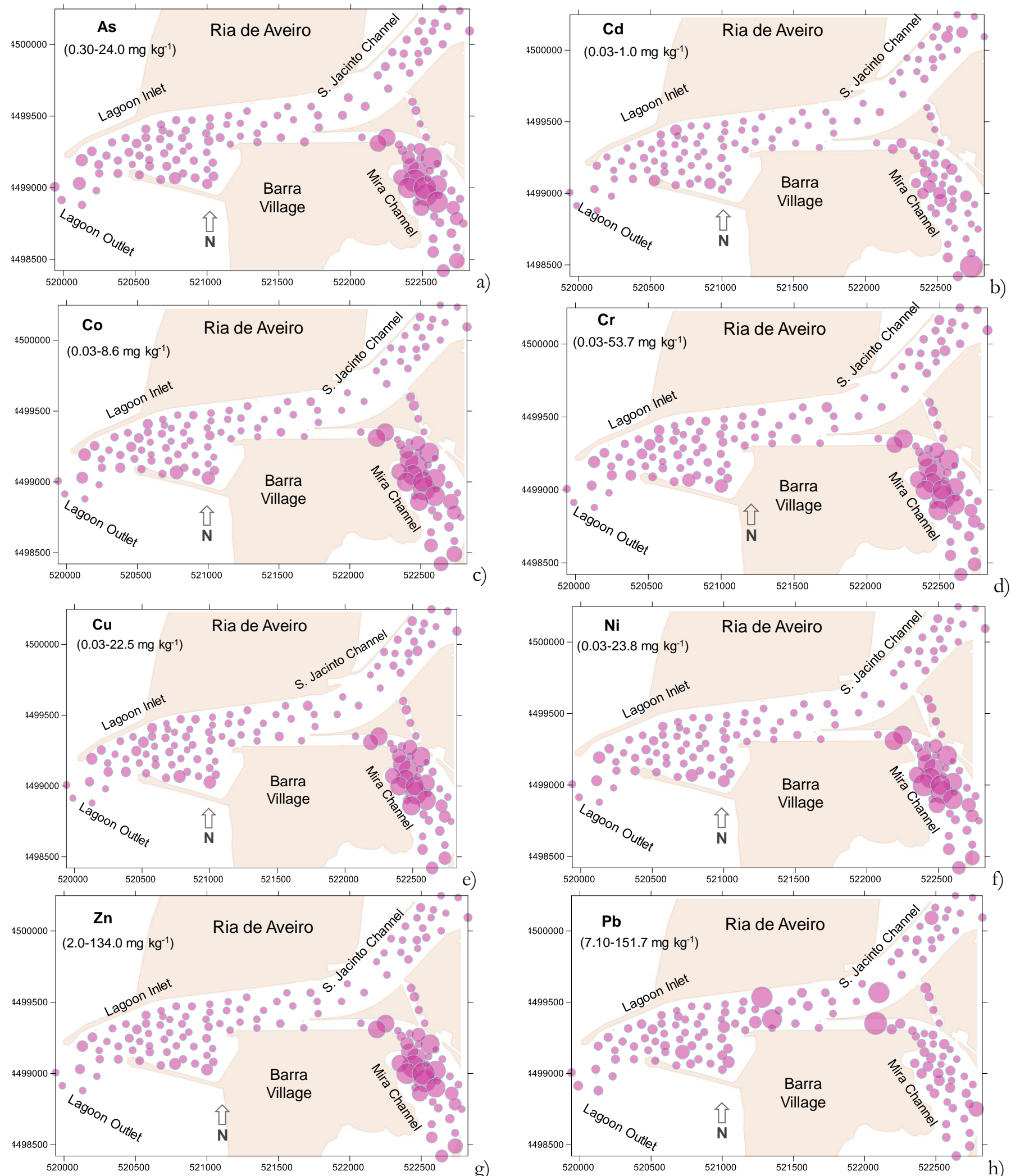

Fig. 3. Pattern of distribution of trace elements concentrations (As, Cd, Co, Cr, Cu, Ni, Pb and Zn; mg kg-1) in Ria de Aveiro mouth. 


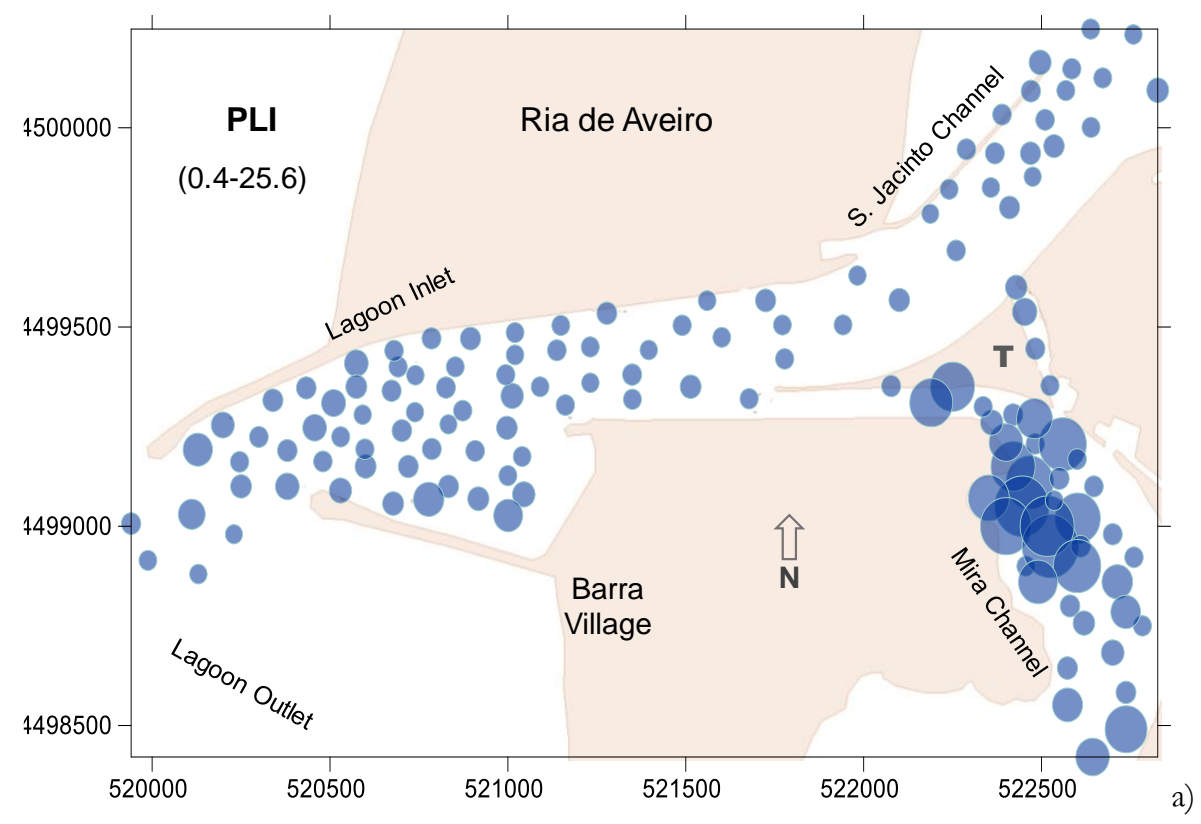

Trace Element Concentrations ( $\left.\mathrm{mg} \mathrm{kg}^{-1}\right)$

350 Mira Channel

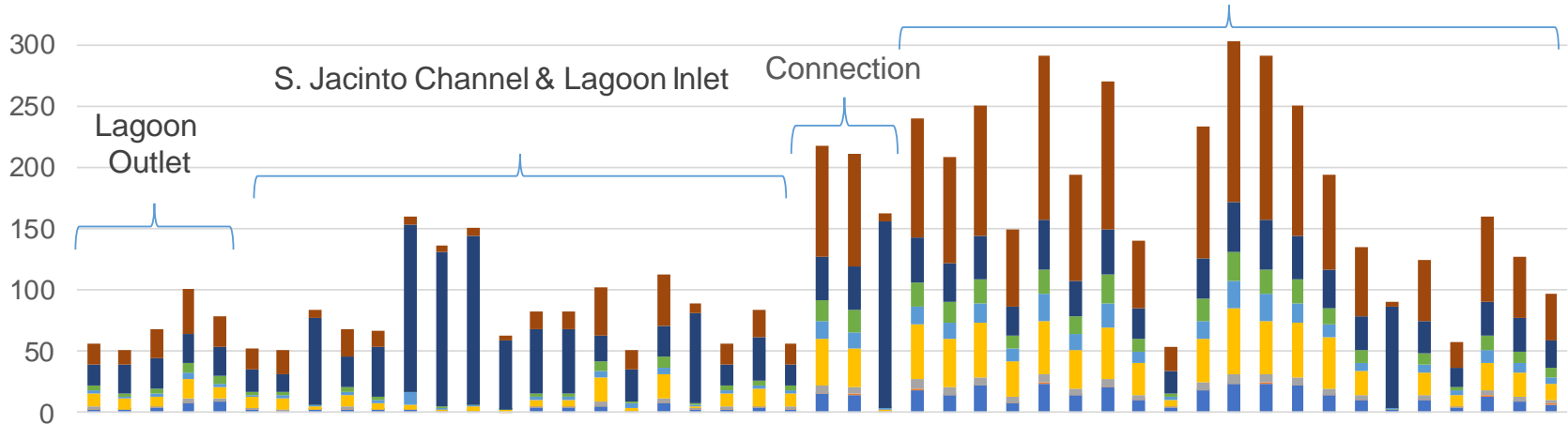

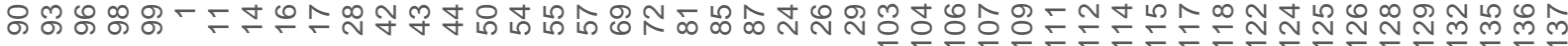

$\square \mathrm{As}=\mathrm{Cd}=\mathrm{Co} \approx \mathrm{Cr}$

- $\mathrm{Cu}=\mathrm{Ni}=\mathrm{Pb} \approx \mathrm{Zn}$
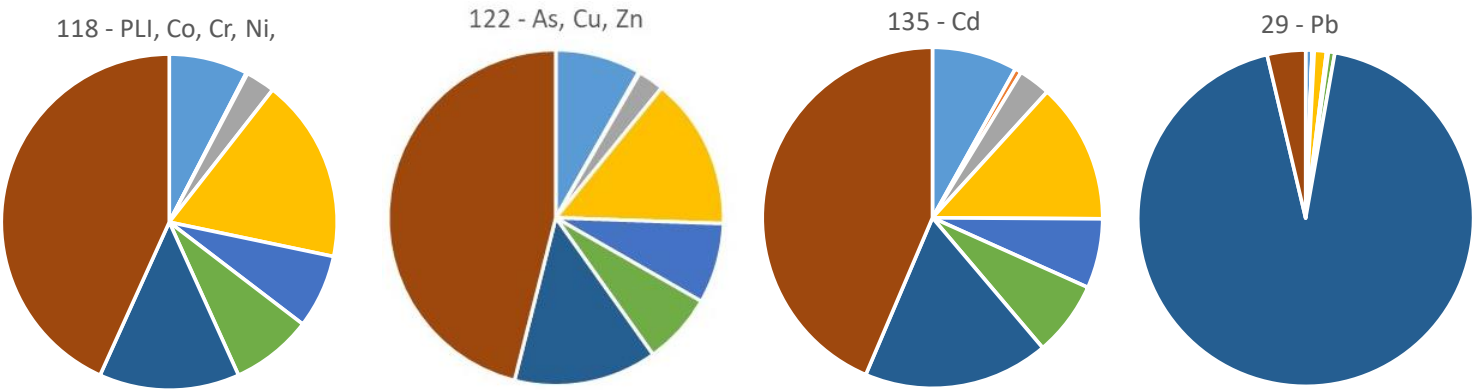

c)

Fig. 4. a) Pattern of distribution of PLI values in Ria de Aveiro mouth. b) Trace element concentrations in the sites where the total concentrations of $\mathrm{As}, \mathrm{Cd}, \mathrm{Co}, \mathrm{Cr}, \mathrm{Cu}, \mathrm{Ni}, \mathrm{Pb}$ and $\mathrm{Zn}$ are higher than $50 \mathrm{mg} \mathrm{kg}^{-1}$. c) Pie charts showing the relative concentration of metals at selected sites (indicated by the number) where each analyzed trace element reached the highest concentration. Legend: $\mathrm{T}$ triangle separator of currents. 

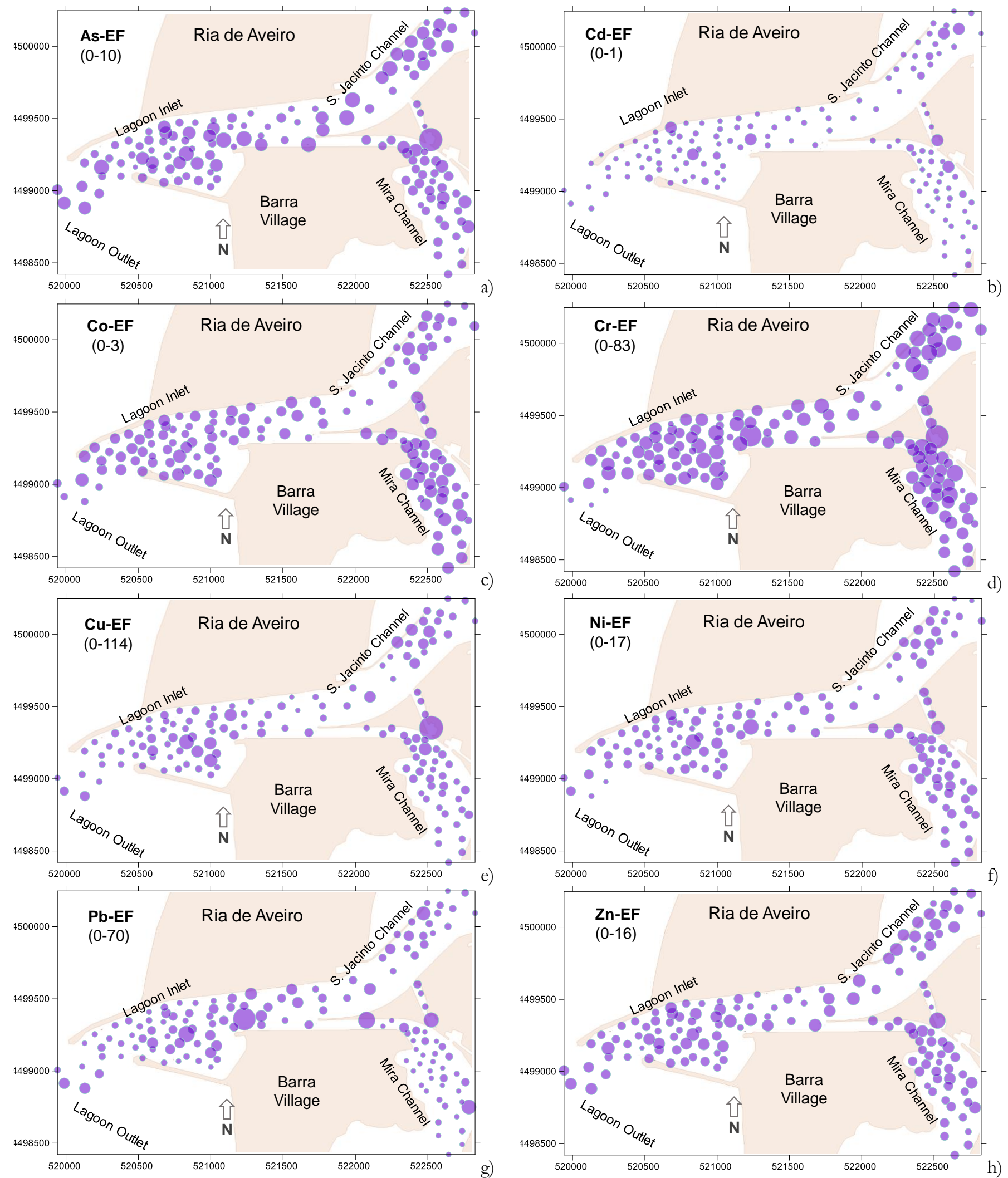

Fig. 5. Pattern of distribution of the enrichment factors (EF) in Ria de Aveiro mouth for: a) As; b) Cd; c) Co; d) Cr; e) $\mathrm{Cu}$; f) Ni; g) $\mathrm{Pb}$ and; h) Zn. 
Tab. 1. Correlations between the analyzed variables. Marked correlations (red) are significant at p < 0.05. Legend: SMGS - sediment mean grain size; Qtz - quartz; KFeld - K-feldspars; Plag - plagioclase; Calc - calcite; Dol - dolomite; Phyl - phyllosilicates

\begin{tabular}{|c|c|c|c|c|c|c|c|c|c|c|c|c|c|c|c|c|c|c|c|}
\hline Variables & Depth & SMGS & As & $\mathrm{Cd}$ & Co & $\mathrm{Cr}$ & $\mathrm{Cu}$ & $\mathrm{Ni}$ & $\mathbf{P b}$ & Sc & $\mathrm{Zn}$ & PLI & TOC & Qtz & K-Feld & Plag & Calc & Dol & Phyl \\
\hline Depth & 1.0 & 0.6 & -0.4 & -0.3 & -0.5 & -0.4 & -0.4 & -0.5 & -0.1 & -0.4 & -0.5 & -0.5 & -0.5 & 0.1 & 0.0 & -0.4 & -0.1 & -0.2 & -0.4 \\
\hline SMGS & 0.6 & 1.0 & -0.6 & -0.4 & -0.6 & -0.5 & -0.5 & -0.6 & -0.2 & -0.6 & -0.6 & -0.6 & -0.7 & 0.2 & 0.1 & -0.4 & -0.2 & -0.1 & -0.4 \\
\hline As & -0.4 & -0.6 & 1.0 & 0.6 & 0.9 & 0.8 & 0.8 & 0.9 & 0.3 & 0.9 & 0.9 & 0.9 & 0.6 & -0.3 & -0.2 & 0.4 & 0.2 & 0.3 & 0.5 \\
\hline Cd & -0.3 & -0.4 & 0.6 & 1.0 & 0.6 & 0.4 & 0.6 & 0.6 & 0.1 & 0.6 & 0.6 & 0.6 & 0.5 & -0.2 & -0.3 & 0.1 & 0.3 & 0.2 & 0.4 \\
\hline Co & -0.5 & -0.6 & 0.9 & 0.6 & 1.0 & 0.9 & 0.8 & 1.0 & 0.4 & 1.0 & 1.0 & 1.0 & 0.6 & -0.3 & -0.2 & 0.4 & 0.3 & 0.4 & 0.5 \\
\hline $\mathrm{Cr}$ & -0.4 & -0.5 & 0.8 & 0.4 & 0.9 & 1.0 & 0.8 & 0.9 & 0.3 & 0.9 & 0.9 & 0.9 & 0.6 & -0.3 & -0.3 & 0.3 & 0.3 & 0.4 & 0.5 \\
\hline $\mathrm{Cu}$ & -0.4 & -0.5 & 0.8 & 0.6 & 0.8 & 0.8 & 1.0 & 0.9 & 0.3 & 0.8 & 0.9 & 0.9 & 0.6 & -0.3 & -0.3 & 0.3 & 0.4 & 0.3 & 0.5 \\
\hline $\mathbf{N i}$ & -0.5 & -0.6 & 0.9 & 0.6 & 1.0 & 0.9 & 0.9 & 1.0 & 0.4 & 0.9 & 1.0 & 1.0 & 0.6 & -0.3 & -0.2 & 0.4 & 0.3 & 0.4 & 0.5 \\
\hline $\mathrm{Pb}$ & -0.1 & -0.2 & 0.3 & 0.1 & 0.4 & 0.3 & 0.3 & 0.4 & 1.0 & 0.4 & 0.4 & 0.4 & 0.2 & -0.2 & 0.1 & 0.3 & 0.2 & 0.1 & 0.2 \\
\hline Sc & -0.4 & -0.6 & 0.9 & 0.6 & 1.0 & 0.9 & 0.8 & 0.9 & 0.4 & 1.0 & 0.9 & 1.0 & 0.6 & -0.3 & -0.3 & 0.4 & 0.3 & 0.4 & 0.5 \\
\hline $\mathrm{Zn}$ & -0.5 & -0.6 & 0.9 & 0.6 & 1.0 & 0.9 & 0.9 & 1.0 & 0.4 & 0.9 & 1.0 & 1.0 & 0.6 & -0.3 & -0.2 & 0.4 & 0.4 & 0.4 & 0.5 \\
\hline PLI & -0.5 & -0.6 & 0.9 & 0.6 & 1.0 & 0.9 & 0.9 & 1.0 & 0.4 & 1.0 & 1.0 & 1.0 & 0.6 & -0.3 & -0.3 & 0.4 & 0.4 & 0.4 & 0.5 \\
\hline TOC & -0.5 & -0.7 & 0.6 & 0.5 & 0.6 & 0.6 & 0.6 & 0.6 & 0.2 & 0.6 & 0.6 & 0.6 & 1.0 & -0.2 & -0.1 & 0.4 & 0.2 & 0.2 & 0.4 \\
\hline Qtz & 0.1 & 0.2 & -0.3 & -0.2 & -0.3 & -0.3 & -0.3 & -0.3 & -0.2 & -0.3 & -0.3 & -0.3 & -0.2 & 1.0 & 0.0 & -0.3 & 0.1 & 0.0 & -0.2 \\
\hline K-Feld & 0.0 & 0.1 & -0.2 & -0.3 & -0.2 & -0.3 & -0.3 & -0.2 & 0.1 & -0.3 & -0.2 & -0.3 & -0.1 & 0.0 & 1.0 & 0.3 & -0.2 & -0.1 & 0.0 \\
\hline Plag & -0.4 & -0.4 & 0.4 & 0.1 & 0.4 & 0.3 & 0.3 & 0.4 & 0.3 & 0.4 & 0.4 & 0.4 & 0.4 & -0.3 & 0.3 & 1.0 & 0.1 & 0.2 & 0.4 \\
\hline Calc & -0.1 & -0.2 & 0.2 & 0.3 & 0.3 & 0.3 & 0.4 & 0.3 & 0.2 & 0.3 & 0.4 & 0.4 & 0.2 & 0.1 & -0.2 & 0.1 & 1.0 & 0.1 & 0.1 \\
\hline Dol & -0.2 & -0.1 & 0.3 & 0.2 & 0.4 & 0.4 & 0.3 & 0.4 & 0.1 & 0.4 & 0.4 & 0.4 & 0.2 & 0.0 & -0.1 & 0.2 & 0.1 & 1.0 & 0.2 \\
\hline Phyl & -0.4 & -0.4 & 0.5 & 0.4 & 0.5 & 0.5 & 0.5 & 0.5 & 0.2 & 0.5 & 0.5 & 0.5 & 0.4 & -0.2 & 0.0 & 0.4 & 0.1 & 0.2 & 1.0 \\
\hline
\end{tabular}

The organic matter present in the sediments of the lagoon mouth area can result of natural productivity or can be introduced as organic waste (Martins, et al., 2015). The natural productivity should also be stimulated by the anthropic introduction of nutrients. Agricultural fields located near the lagoon mouth may contribute with phosphates and nitrates, which may stimulate the growth of algae and aquatic plants and all natural food chains. Due to the good connection with the ocean the water is renewed twice daily by tidal currents, being therefore generally well oxygenated in this zone (Lopes et al., 2005). Heterotrophic activity in the lagoon is intense and respiration rate and total aerobic carbon remineralisation relatively high (Cunha et al., 1999, 2003).
As observed by Martins et al. (2015, 2016), sedimentary organic matter content reaches, in general, the highest concentrations in internal regions of Ria de Aveiro and decreases towards the mouth of the lagoon so also the concentration of metals does. However, the PLI index shows that the area with highest enrichment of metals is the western side of the Mira Channel entrance that is a calmer zone where finer sediments and higher organic matter content are deposited as well as relatively high metals concentrations are found. The increase of PTEs concentrations in this area should result from human activity. Barra village located at the western margin of Mira Channel, has variable human population density. 


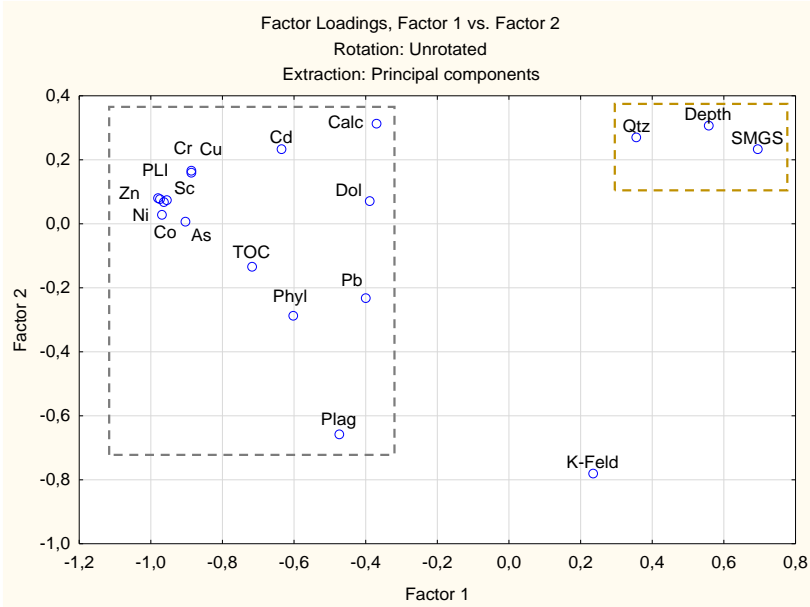

Fig. 6. PCA plot of the Factor 1 against the Factor 2 evidencing the main relationships between the variables.

The region is used for tourism and holiday becoming densely populated in summer. It is surrounded by harbour structures and associated commercial and industrial activities. This anthropic presence may result in the dumping of waste and improper products into the lagoon.

According to the classification of EF of Sutherland et al. (2000), eighty-three stations of the study area have significant enrichment of metals especially $\mathrm{Pb}$ and $\mathrm{Cr}$; the significant enrichment by $\mathrm{Cr}$ is the most common, being by $\mathrm{Pb}$ punctually. The EF reached highest values: in station 9 with extremely high enrichment by $\mathrm{Cu}$ and $\mathrm{Cr}$ and moderate enrichment by $\mathrm{Zn}$, As and $\mathrm{Ni}$ and; in station 44, indicating extremely high enrichment by $\mathrm{Cr}$ and $\mathrm{Pb}$ and moderate enrichment by $\mathrm{Ni}$ and $\mathrm{Zn}$.

As mentioned, the sediments in the study area are frequently dredged for deepening of navigable channels and avoid the sediment accumulation to allow access of large and heavily loaded vessels and coastal boats to the port. The Portuguese Ministerial Order n. ${ }^{\circ} 1450 / 2007$ (Portaria $n^{\circ}$ 1450/2007) of the "Ministro do Ambiente, do Ordenamento do Território e do Desenvolvimento Regional" (Minister for the Environment, Spatial Planning and Regional Development), provides information about the determination of the characteristics and composition of the dredged material for the purpose of dredging and elimination or application of these materials. This regulation requires prior dredging evaluation. If the initial analysis indicates significant contamination, the area must be studied and monitored. The results must be representative of the column of sediments to be dredged, that is, from the surface to the base of dredging, except for materials with particle size $>2$ $\mathrm{mm}$. In order to assess the levels of contamination, this regulation requires sedimentological analyses including, for instance, particle size (percentage of sand, silt and clay fraction), total organic carbon $(<2 \mathrm{~mm})$ and chemical ones. In the presence of contamination, it is mandatory to analyse the substances that may be present due to specific and diffuse sources of pollution.

The Portuguese Ministerial Order n. ${ }^{\circ}$ 1450/2007 (Portaria n. ${ }^{\circ}$ 1450/2007) classifies the sediments according to degree of contamination by metals $\left(\mathrm{mg} \mathrm{kg}^{-1}\right)$ into five categories (Table 2). Based on it, it can be observed that in the study area for (Appendix 2):

a) As, the sediment of most of the stations belonged to class 1 ([As] $<20 \mathrm{mg} \mathrm{kg}^{-1}$ ) and that found in the stations 106, 109, $112,118,122,124$ to the class $2\left(20 \mathrm{mg} \mathrm{kg}^{-1}<[\mathrm{As}]<50 \mathrm{mg}\right.$ $\left.\mathrm{kg}^{-1}\right)$;

b) Cd, the sediment of most of the stations belonged to class $1\left([\mathrm{Cd}]<1 \mathrm{mg} \mathrm{kg}^{-1}\right)$ and station 135 to class $2\left(1 \mathrm{mg} \mathrm{kg}^{-1}<\right.$ [Cd] $\left.<3 \mathrm{mg} \mathrm{kg}^{-1}\right)$;

c) Co, there are no classification for dredged materials;

d) $\mathrm{Cr}$, the sediment of all the stations belonged to class 1 ([Cr] $\left.<50 \mathrm{mg} \mathrm{kg}^{-1}\right)$, except the station 118 that belonged to class $2\left(50 \mathrm{mg} \mathrm{kg}^{-1}<[\mathrm{Cr}]<100 \mathrm{mg} \mathrm{kg}^{-1}\right)$;

e) $\mathrm{Cu}$, the sediment of all the stations belonged to class $1([\mathrm{Cu}]$ $<35 \mathrm{mg} \mathrm{kg}^{-1}$ );

f) $\mathrm{Ni}$, the sediment of all the stations belonged to class 1 ([Ni] $<30 \mathrm{mg} \mathrm{kg}^{-1}$ );

g) $\mathrm{Pb}$, the sediment of most the stations belonged to class 1 $\left([\mathrm{Pb}]<50 \mathrm{mg} \mathrm{kg}^{-1}\right)$ but some stations (14, 28, 42, 43, 44, $50,54,72$ and 128) can be included in the class $2(50 \mathrm{mg}$ $\mathrm{kg}^{-1}<[\mathrm{Pb}]<150 \mathrm{mg} \mathrm{kg}^{-1}$ ) and station 29 in the class 3 $\left(150 \mathrm{mg} \mathrm{kg}^{-1}<[\mathrm{Pb}]<500 \mathrm{mg} \mathrm{kg}^{-1}\right)$;

h) $\mathrm{Zn}$, the sediment of most the stations belonged to class 1 and some stations $(106,109,112,117,118,122,124)$ to class $2(100 \mathrm{mg} \mathrm{kg}-1<[\mathrm{Zn}]<600 \mathrm{mg} \mathrm{kg}-1)$.

In most of the stations, sediments of Class 1 were found (Fig. 7; appendix 2), corresponding to clean dredged material, that may be deposited in the aquatic environment or replaced in places subject to erosion or used for beach nourishment or replenishment without restrictions. Sixteen sites were classified as Class 2 (Fig. 7; appendix 2), dredged material with trace contamination, that may be immersed in the aquatic environment taking into account the characteristics of the receiving environment and its legitimate use; the station 29, located laterally to the triangle separator of currents, which connect the Mira and S. Jacinto channels, was classified as Class 3 (Fig. 7; appendix 2), slightly contaminated dredged material, that may be used for embankments or in the case of soaking requires a thorough study of the place of deposition and subsequent monitoring thereof.

According to the values presented in the Portuguese Ministerial Order n. ${ }^{\circ}$ 1450/2007 (Portaria n. ${ }^{\circ}$ 1450/2007), the study area has not sediments of Class 4 , contaminated 
dredged material, which must be deposited in land, in a waterproofed place, and Class 5, considered highly contaminated material, which should not be dredged and, in case of imperative, the dredgers must be subjected for previous treatment and/or dump of duly authorized waste, being prohibited their immersion.

The data presented in this study only includes the first $\mathrm{cm}$ of sediment and not the geochemical analysis of sedimentary cores that would allow the evaluation of the state of contamination of the sedimentary column. Data are reported to $2006 / 2007$, and not current as mentioned in the methodology section, but the sediments may have a quite long memory of the sedimentary processes mainly in areas where accumulation dominates over erosion effects. The results of this work allow the identification of an area of metals enrichment, located in the Mira Channel entrance but mostly at the western side and alert for the possible occurrence of PTEs enrichment dispersed through all the channels of the Ria de Aveiro lagoon mouth (Figures 4, 5, 7).

On the other hand, the geochemical results presented in this work were obtained by total digestion of the sediment, which extracts quantitatively all the elements of the sediment including those that are retained in the crystallochemical structure of the minerals. This component may be considerable as observed by Martins et al. (2010). In fact, a method that does not quantitatively extract all elements of the sediment, but only those that are potentially available by natural leaching or biological processes would be more suitable for this type of analysis.

Tab. 2. Classification of materials according to degree of contamination: metals $\left(\mathrm{mg} \mathrm{kg}^{-1}\right)$, considering values proposed Long et al., 1995 and adopted by the Brazilian regulation CONAMA 344/2004 and according to FDEP (1994) and to the Portuguese Ministerial Order n. ${ }^{\circ} 1450 / 2007$ (Portaria n. ${ }^{\circ}$ 1450/2007).

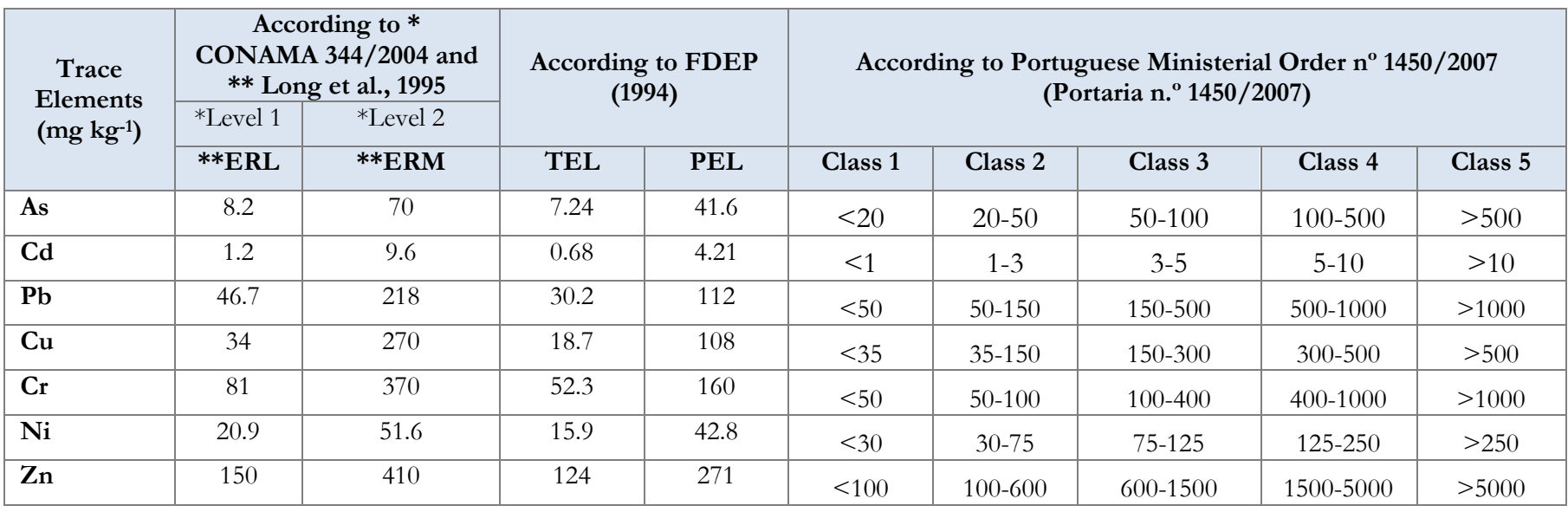

The Portuguese Ministerial Order n. ${ }^{\circ} 1450 / 2007$ (Portaria n. ${ }^{\circ} 1450 / 2007$ ) has not clear instructions about the methodology to be applied in the geochemical analysis. The same occurs too in other developed sediment quality criteria such as that of: i) FDEP (1994) of the Florida Department of Environmental Protection that determined two levels of contamination: the threshold effect level (TEL), which is the concentration at which effects rarely occur, and the probable effect level (PEL), which is the concentration at which effects are likely to occur (Table 2); ii) Long et al. (1995) that considered two guideline values for trace metals, effects range-low (ERL) and effects range-median (ERM), that define concentration ranges that are rarely $(<\mathrm{ERL})$, occasionally (between ERL and ERM), or frequently ( $>$ ERM) cause of adverse effects (Table 2); iii) the CONAMA
344/2004, of the Brazilian National Council for the Environment (Conselho Nacional do Meio Ambiente), based on Long et al. (1995).

Tessier et al. (1979) considered five different sediment chemical fractions: 1) exchangeable, PTEs adsorbed to clays: $\mathrm{F} 1_{\text {Tess }}$ are the most bioavailable and are readily released by complexation and minor $\mathrm{pH}$ changes; 2) acid-soluble, PTEs bound to carbonates: $\mathrm{F} 2$ Tess $-\mathrm{CO}_{3}$ can be released during dissolution; 3) reducible, PTEs bound to oxidized minerals: $\mathrm{F}$ Tess $^{-}$ $\mathrm{Fe} / \mathrm{Mn}$ can be released in reducing conditions; 4) oxidable, PTEs bound to organic matter: $\mathrm{F} 4_{\text {Tess }}$-organic matter and; 5) residual, PTEs found in the crystalline structure of silicate minerals: F5 Tess-lithics are the least bioavailable and will not be released to the environment). 
Trace metals fractionation and the available concentrations of metal in the sediment are affected by many factors such as (a) grain size, in general the finer sediments have greater capacity for metals retaintion; (b) organic matter content; (c) physical-chemical parameters such as $\mathrm{pH}, \mathrm{Eh}$, salinity, oxygenation (oxygenated, hypoxic and anoxic conditions) among other environmental factors that can influence biogeochemical reactions in the sediment (Zaaboub et al., 2015, 2016; Oueslati et al., 2017).

Factors that influence metal speciation also include (Yokel, et al., 2006): 1) carrier-mediated processes for specific metal species (e.g. As, $\mathrm{Cr}$ and $\mathrm{Pb}$ ); 2) valence state (e.g. As and $\mathrm{Cr}$ ); 3) particle size (e.g. $\mathrm{Pb}$ ); 4) the nature of metal binding ligands (e.g. As, $\mathrm{Cr}$ and $\mathrm{Pb}$ ); 5) whether the metal is an organic versus inorganic species (e.g. As and $\mathrm{Pb}$ ) and; 6) biotransformation of metal species (e.g. As, $\mathrm{Cr}$ and $\mathrm{Pb}$ ).

Murray and Meinke (1974) demonstrated, for instance, that in the presence of organic matter the adsorption of $\mathrm{Co}$ and $\mathrm{Cd}$ can be reduced and whereas the adsorption of $\mathrm{Zn}$ can increase. Under oxic conditions, PTEs (e.g., Cu, Pb, Zn) are sequestered by $\mathrm{Fe} / \mathrm{Mn}$ oxides and, conversely, in anoxic environments, by sulfides (Davies et al., 2005; Larios et al., 2012; Zaaboub et al., 2015).

In addition, it is expected that in very dynamic systems the geochemical environment can be very dynamic with some changes in the chemical environment occurring on day-night cycles, tidal cycles, and particularly with storm activity that induces mixing.

Beyond having an increased socioeconomic value when used as materials for several purposes, the sediments are the basis for supporting aquatic life (habitats) and providing nutrients (Brils, 2008). Sediments have therefore a very significant ecological value mostly in marine and transitional systems (Warwick et al., 1991). In these settings, the toxicity of metals, which should be influenced by speciation, may differently affect the living beings. The PTEs toxicity depends on several factors including the dose, route of exposure, and chemical species, as well as the age, gender, genetics, and nutritional status of exposed individuals (Tchounwou et al., 2012). For public health and due to their high degree of toxicity, $\mathrm{As}, \mathrm{Cd}, \mathrm{Cr}, \mathrm{Pb}$, and $\mathrm{Pb}$ are among the priority metals of concern (Tchounwou et al., 2012). These metallic elements are considered systemic toxicants that are known to induce multiple organ damage, even at lower levels of exposure (Tchounwou et al., 2012). They are also classified as human carcinogens according to the U.S. Environmental Protection Agency, and the International Agency for Research on Cancer.

Several studies based on available concentrations of PTEs in sediments and their effects on protozoans (foraminifera) have used as bioindicators of environmental quality, such as those of Martins et al. (2010, 2011, 2013, 2015, 2016) in Ria de Aveiro. Martins et al. (2010) analysed the concentrations of PTEs for exchangeable cations adsorbed by clay and elements co-precipitated with carbonates and for elements adsorbed by organic matter (humic and fulvic compounds) and Martins et al. (2015) also considered the elements adsorbed by amorphous $\mathrm{Mn}$ hydroxide.

These studies were not conclusive about the most toxic contaminated sedimentological phase by PTEs for foraminifera, because the concentrations associated to all these phases increased simultaneously in the most polluted sediments. However, it is assumed that the increasing of metals concentrations in organic matter (food source) may present highest toxicity for these organisms. In fact, it was not still identified which sediment fraction of the contaminated sediments has the highest toxicity for organisms that live in marine and transitional environments.

Martins et al. (2015) noticed that sediments collected in several channels of the Ria de Aveiro had the highest available concentrations of $\mathrm{As}, \mathrm{Cd}, \mathrm{Co}, \mathrm{Ni}, \mathrm{Pb}$ and $\mathrm{Zn}$ adsorbed by amorphous Mn-hydroxides than in other phases. On the other hand, the highest available concentrations of $\mathrm{Cu}$ and $\mathrm{Hg}$ and in some stations of $\mathrm{Cs}$ were mostly found adsorbed by organic matter. Lead also presented relatively high available concentrations adsorbed by clay minerals and precipitated by carbonates. But, the other PTEs presented in general lower available concentrations in this phase than that found in the other two mentioned sediment fractions. However, as observed by Tessier et al. (1979) and Zaaboub et al. (2015), the highest mobility of PTEs is related to exchangeable portion of the $\mathrm{F} 1_{\text {Tess }}$ fraction that is largely controlled by $\mathrm{pH}$ and redox conditions.

\section{Conclusion}

This work shows the general distribution pattern of PTEs in surface sediments at the mouth of the Ria de Aveiro. It allows to verify that there is a preferential zone of increase of the concentrations of metals in the Mira Channel, namely As, Co, Cr, Cu, Ni and Zn

The EF values indicate significant enrichment of metals, particularly $\mathrm{Pb}$ and $\mathrm{Cr}$ in a significant number of samples in the study area, being the enrichment in $\mathrm{Cr}$ more common than that of $\mathrm{Pb}$, which occurs punctually in some stations. A small number of stations should have very high enrichment or extremely high enrichment of $\mathrm{Cr}$ and $\mathrm{Pb}$. 


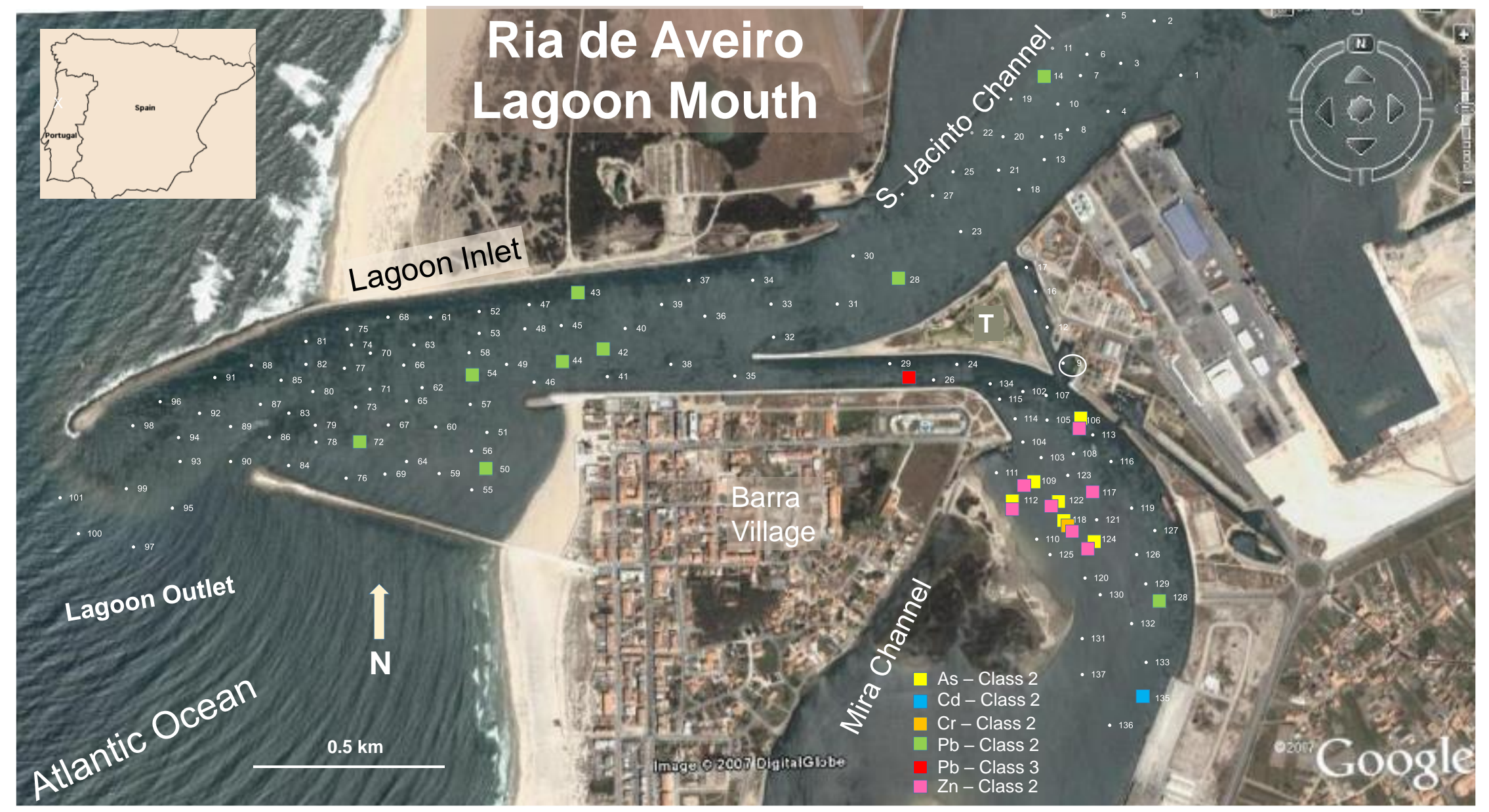

Fig. 7. Classification of the sediments at Ria de Aveiro Lagoon mouth (image adapted from Google Earth) according to the Portuguese regulation (Appendix 2). 
According to the Portuguese legislation, most of the sites analyzed in this work are not polluted or have low values of contamination by PTEs but locally contamination occurs. Portuguese legislation and sediment guidelines are omitted or unclear in relation to the methodology to be applied in the geochemical analysis of sediments for dredging considering that contaminants can be associated with different sedimentological phases. PTEs associated to different sedimentary fractions should have differential mobility and impact on living organisms. Thus, the clarification of procedures for geochemical analysis to be applied in environmental regulation to evaluate the sediments quality is necessary and welcome prerequisite.

\section{Acknowledgment}

The authors also would like to thank the financial support given by the "Fundação para a Ciência e a Tecnologia" (FCT, Portugal) through the EMERA Project (POCTI/ECM/59958/2004) and the strategic project UID/GEO/04035/2013. The authors also would like to thank very much Prof. João Miguel Dias (the coordinator of EMERA project), and Prof. Isabel Abrantes and Mr. Rui Marques, of Aveiro University, for the valuable collaboration and to the Department of Biology of Aveiro University for the vessel advance used during the fieldwork.

Appendices 1-2 are attached as supplementary materials (SM1SM2) in http://www.e-

publicacoes.uerj.br/index.php/jse/article/view/30055

\section{References}

Abrahim, G.M.S., Parker, R.J., 2008. Assessment of heavy metal enrichment factors and the degree of contamination in marine sediments from Tamaki Estuary, Auckland, New Zealand. Environmental Monitoring and Assessment 136, 227-238.

Aguiar, J.E., Marins, R.V., Almeida, M.D., 2007. Comparação de metodologias de digestão de sedimentos marinhos para caracterização da geoquímica de metais-traço na plataforma continental nordeste oriental brasileira. Geochimica Brasiliensis 21(3), 304-323.

Barcellos, R.L., Figueira, R.C.L., França, E.J., Schettini, C.A., Xavier, D.A., 2017. Changes of estuarine sedimentation patterns by urban expansion: the case of Middle Capibaribe Estuary, Northeastern Brazil. International Journal of Geosciences 8 (4). doi: 10.4236/ijg.2017.84027

Begy, R.-C., Preoteasa, L., Timar-Gabor, A., Mihaiescu, R., Tanaselia C., Kelemen, S., Simon, H., 2016. Sediment dynamics and heavy metal pollution history of the Cruhlig Lake (Danube Delta, Romania). Journal of Environmental Radioactivity 153, 167-175. doi.org/10.1016/j.jenvrad.2015.12.020

Brils, J., 2008. Sediment monitoring and the European Water Framework Directive. Annali dell'Istituto Superiore di Sanità 44 (3), 218-223.

Cai, F., Su, X., Lib, J., Li, B., Leia, G., 2009. Coastal erosion in
RESEARCH PAPER

China under the condition of global climate change and measures for its prevention. Progress in Natural Science 19 (4), 415-426.

Castro, S.M. de, Almeida, J.R. de., 2012. Dragagem e conflitos ambientais em portos clássicos e modernos: uma revisão. Sociedade and Natureza 24 (3), 519-534. Retrieved from http://www.scielo.br/pdf/sn/v24n3/v24n3a11.pdf

Chapman, P.M., Wang, F., 2001. Assessing sediment contamination in estuaries. Environmental Toxicology and Chemistry 20(1), 3-22. doi: 10.1002/etc.5620200102

Coelho, C., Silva, P.A., Pinheiro, L.A., Gonçalves, D.S., 2011 (eds.), Dragagens: Fundamentos, Técnicas e Impactos. Universidade de Aveiro, Aveiro, Portugal.

CONAMA - Conselho Nacional do Meio Ambiente, 2004. Resolução No 344, de 25 de Março de 2004, Publicada no DOU $n^{\circ} 087$, de $07 / 05 / 2004$, pp. 56-57.

Cronin, R., 2009. Natural Resources and the DevelopmentEnvironment Dilemma. Exploiting Natural Resources. The Henry L. Stimson Centre, p. 63.

Cruz, M.A.S., Santos, L.T.S.D.O., Lima, L.G.L.M., Jesus, T.B., 2013. Caracterização granulométrica e mineralógica dos sedimentos como suporte para análise de contaminação ambiental em nascentes do rio Subaé, Feira de Santana (BA). Geochimica Brasiliensis 27 (1), 49-62. doi. org/10.5327/Z0102-9800201300010005

Cunha, M.A., Almeida, M.A., Alcântara, F., 1999. Compartments of oxygen consumption in a tidal mesotrophic estuary (Ria de Aveiro, Portugal). Acta Oecologica 20 (4), 227-235.

Cunha, M.A., Almeida, M.A., Alcântara, F., 2003. Ectoenzymatic activity and glucose heterotrophic metabolism in a shallow estuary (Ria deAveiro, Portugal): influence of bed sediments and salt marshes. Acta Oecologica 24, S97-S107

Davies, B.E., Bowman, C., Davies, T. C., Selinus, O., 2005. Medical Geology: Perspectives and prospects. In: Selinus, O., Alloway, B., Centeno, J. A., Finkelman, R. B., Fuge, R., Lindh, U., and Smedley, P. (eds.), Essentials of Medical Geology. Elsevier Academic Press, New York, pp. 1-41.

Dias, J.M.A., Boski, T., Rodrigues, A., Magalhães, F., 2000. Coast line evolution in Portugal since the Last Glacial Maximum until present - A synthesis. Marine Geology, 170 (1-2), 177-186. doi.org/10.1016/S0025-3227(00)00073-6

FDEP, 1994. Approach to the Assessment of Sediment Quality in Florida Coastal Waters. Vol. I. Development and Evaluation of Sediment Quality Assessment Guidelines. Prepared for Florida Department of Enviromental Protection - FDEP, Office of Water Policy, Tallahasee, FL, by MacDonald Enviromental Sciences Ltd., Ladysmith, British Columbia.

Ferreira, A.M.P.J., 2000. Capítulo 2, Caracterização de Portugal Continental. Dados Geoquímicos de Base de Sedimentos Fluviais de Amostragem de Baixa Densidade de Portugal Continental: Estudo de Factores de Variação Regional. LNEG. Retrieved from http://www.lneg.pt/download/3259/cap2.pdf

Folk, R.L., Ward, W.C., 1957. Brazos River bar: a study in the significance of grain size parameters. Journal of Sedimentary Petrology 27, 3-26.

Greene, K., 2005. Beach nourishment: A review of the biological and physical impacts, Atlantic States Marine Fisheries Commission, ASMFC Habitat Management Series Number 7.

Harikumar, P.S., Nasir, U.P., Mujeebu Rahma, M.P., 2009. Distribution of heavy metals in the core sediments of a tropical 
wetland system. International Journal of Environmental Science Technology 6 (2), 225-232.

Harrington, J., Smith, G., 2013. Guidance on the beneficial use of dredge material in Ireland. Report commissioned by Environmental Protection Agency, STRIVE Small Scale Study Programme, Cork Institute of Technology.

Jouanneau, J.M., Latouche, C., 1981. The Gironde Estuary. E. Schw. Verlagchh., Stuttgart, pp. 115.

Larios, R., Fernández-Martínez, R., Rucandio, I., 2012. Comparison of three sequential extraction procedures for fractionation of arsenic from highly polluted mining sediments. Analytical and Bioanalytical Chemistry 402, 2909-2921. doi:10.1007/s00216-012-5730-3

Lima, M. C., Giacomelli, M. B. O., Stüpp, V., Roberge, F. D., and Barrera, P. B. (2001). Especiação de cobre e chumbo em sedimento do Rio Tubarão (SC) pelo método tessier. Quimica Nova, 24(6), 734-742. doi.org/10.1590/S0100-40422001000600005

Liu, Q.T., Diamond, M.L., Gingrinch, S.E., Ondov, J.M., Maciejczyk, P., Stern, G.A., 2003. Accumulation of metals, trace elements and semi-volatile organic compounds on exterior window surfaces in Baltimore. Environmental Pollution 122, 51-61. doi.org/10.1016/S0269-7491(02)00286-5

Long, E.R., MacDonald, D.D., Smith, S.L., Calder, F.D., 1995. Incidence of adverse biological effects within ranges of chemical concentrations in marine and estuarine sediments. Environmental Management 19 (1), 81-97.

Lopes, J.F., Dias, J.M., Cardoso, A.C., Silva, C.I.V., 2005. The water quality of the Ria de Aveiro lagoon, Portugal: From the observations to the implementation of a numerical model. Marine Environmental Research 60, 594-628. doi. org/10.1016/j.marenvres.2005.05.001

Marine Board, 1985. Dredging Coastal Ports: An Assessment of the Issues. National Research Council, Division on Engineering and Physical Sciences, Commission on Engineering and Technical Systems, Marine Board. National Academy Press, Washington, $212 \mathrm{p}$.

Marmin, S., Dauvin. J.-C. Lesueur, P., 2014. Collaborative approach for the management of harbour-dredged sediment in the Bay of Seine (France). Ocean and Coastal Management 102, Part A, 328-339. doi.org/10.1016/j.ocecoaman.2014.10.012

Martins, M.V.A., Pinto, A.F.S, Frontalini, F., Machado da Fonseca, M.C., Terroso, D.L., Laut, L.L.M., Zaaboub, N., Rodrigues, M.A., Rocha, F., 2016. Can benthic foraminifera be used as bioindicators of pollution in areas with a wide range of physiochemical variability? Estuarine, Coastal and Shelf Science 182, 211-225. doi.org/10.1016/j.ecss.2016.10.011.

Martins, M.V.A., Silva, F., Laut, L.L.M., Frontalini, F., Clemente, I.M.M.M., Miranda, P., Figueira, R., Sousa, S.H.M., Dias, J.M.A., 2015. Response of Benthic Foraminifera to Organic Matter Quantity and Quality and Bioavailable Concentrations of Metals in Aveiro Lagoon (Portugal). PLoS ONE 10. doi: 10.1371/journal.pone.0118077.

Martins, M.V.A., Frontalini, F., Tramonte, K.M., Figueira, R.C., Miranda, P., Sequeira, C., Fernandez-Fernandez, S., Dias, J. A., Yamashita, C., Reno, R., Laut, L.L., Silva, F.S., Rodrigues, M.A., Bernardes, C., Nagai, R., Sousa, S.H., Mahiques, M., Rubio, B., Bernabeu, A., Rey, D., Rocha, F., 2013. Assessment of the health quality of Ria de Aveiro (Portugal): heavy metals and benthic foraminifera. Marine Pollution Bulletin, 70 (1-2), 1833. doi.org/10.1016/j.marpolbul.2013.02.003
Martins, V., Ferreira da Silva, E., Sequeira, C., Rocha, F., Duarte, A.C., 2010. Evaluation of the ecological effects of heavy metals on the assemblages of benthic foraminifera of the canals of Aveiro (Portugal). Estuarine, Coastal and Shelf Science, 87, 293-304. doi: 10.1016/j.ecss.2010.01.011.

Martins, V., Yamashita, C., Sousa, S.H.M., Martins, P., Laut, L.L.M., Figueira, R.C.L., Mahiques, M.M., Ferreira da Silva, E., Dias, J.A.M., Rocha, F., 2011. The response of benthic foraminifera to pollution and environmental stress in Ria de Aveiro (N Portugal). Journal of Iberian Geology 37, 231-246.

Martins, V., Dubert, J., Jouanneau, J.-M., Weber, O., Silva, E.F., Patinha C., Alveirinho Dias, J. M., Rocha, F., 2007. A multiproxy approach of the Holocene evolution of shelf-slope circulation on the NW Iberian Continental Shelf. Marine Geology 239, 1-18. doi.org/10.1016/j.margeo.2006.11.001

McLusky, D.S., Elliott, M., 2004. The Estuarine Ecosystem: Ecology, Threats and Management, Oxford University Press, New York, USA.

MEMG, 2003. Group Co-ordinating Sea Disposal Monitoring. Final Report of the Dredging and Dredged Material Disposal Monitoring Task Team, Science Series Aquatic Environment Monitoring Report, CEFAS, Lowestoft, No 55, pp. 1-52.

Murray, C.N., Meinke, S., 1974. Influence of soluble sewage material on absorption and desorption behaviour of $\mathrm{Ag}, \mathrm{Cd}$, Co and $\mathrm{Zn}$ in sediment-sea water system. Journal of the Oceanographical Society of Japan 30, 216-221.

Nicholson, S., Pomfret, J., Gilligan, E., Mistry, R., 2010. Research and support for developing a UK strategy for managing contaminated marine sediments: Task 5 Establishing Best Practice for Current Disposal and Treatment Options for Contaminated Dredged Marine Sediments.

Ojeda, J., Sanchez, E., Fernandez-Palacios, A., Moreira, J.M., 1995. Study of the dynamics of estuarine and coastal waters using remote sensing: the Tinto-Odiel estuary, SW Spain. Journal of Coastal Conservation 1 (2), 109-118. doi. org/10.1007/BF02905119

Oueslati, W., Zaaboub, N., Helali, M.A., Ennouri, R., Martins, M.V.A., Dhib, A., Galgani, F., El Bour, M., Added, A., Aleya, L., 2017. Trace element accumulation and elutriate toxicity in surface sediment in northern Tunisia (Tunis Gulf, southern Mediterranean). Marine Pollution Bulletin 116 (1-2), 216-225. doi:10.1016/j.marpolbul.2016.12.076

Paiva, R., 2011. Definição do Campo de Actividades de Dragagens. In: Coelho, C. da Silva, P.A. Pinheiro, L.M., Gonçalves, D.S. (eds.), Dragagens: Fundamentos, Técnicas e Impactos Aveiro, Portugal, Administração do Porto de Aveiro, pp. 11-64.

Paixão, G.L., 2004. The fate of dredged material in Portugal: a perspective. SEDNET: 3rd worshop morning sediment quality at basin scale: understanding the behaviour and fate of pollulants. IPortugal: NIAP-IPIMAR, 87-98.

Pan, K., Wang, W.-X, 2012. Trace metal contamination in estuarine and coastal environments in China. Science of The Total Environment 421-422, doi.org/10.1016/j.scitotenv.2011.03.013

Park, C., 2001. The environment: principles and applications. Second Edition, Routledge, Taylor \& Francis Group, New York.

Pethick, J., 2002. Estuarine and tidal wetland restoration in the United Kingdom: Policy versus practice. Restoration Ecology 10 (3), 431-437. doi: 10.1046/j.1526-100X.2002.01033. 
Plecha, S., Silva, P.A., Vaz, N., Bertin, X., Oliveira, A., Fortunato, A.B., Dias, J.M., 2010. Sensitivity analysis of a morphodynamic modeling system applied to a coastal lagoon inlet. Ocean Dynamics 60, 275-284

Plecha, S., Silva, P.A., Oliveira, A., Dias, J.M., 2012. Establishing the wave climate influence on the morphodynamics of a coastal lagoon inlet. Ocean Dynamics. doi 10.1007/s10236-012-0530-z

Poiner, I.R., Kennedy, R., 1984. Complex patterns of change in the macrobenthos of a large sandbank following dredging. Marine Biology 78, 335-352.

Portaria n. ${ }^{\circ}$ 1450/2007, de 12 de Novembro, do Ministério do Ambiente, do Ordenamento do Território e do Desenvolvimento Regional. Diário da República, $1{ }^{a}{ }^{\text {série, }}$ N. ${ }^{\circ}$ 217 , p. $8372-8382$.

Prandle, D., 2009. Estuaries. dynamic, mixing, sedimentation and morphology. Cambridge University press. doi: 10.1017/CBO9780511576096

Prumm, M., Iglesias, G., 2016. Impacts of port development on estuarine morphodynamics: Ribadeo (Spain). Ocean \& Coastal Management 130, 58-72. doi. org/10.1016/j.ocecoaman.2016.05.003

Pye, K., Allen, J.R.L., 2000. Coastal and estuarine environments: sedimentology, geomorphology and geoarchaeology. The Geological Society, London, UK.

Schmidt, L., Mourato, J., 2015. Políticas públicas costeiras e adaptação às alterações climáticas: Que limites de implementação? VIII Congresso Sobre Planeamento e Gestão das Zonas Costeiras dos Países de Expressão Portuguesa, 1-17. Retrieved from ZonasCosteiras2015/pdf/5B3_Artigo_086.pdf

Schmidt, L., Santos, F.D., Prista, P., Saraiva, T., Gomes, C., 2012. Alterações climáticas, sociais e políticas em Portugal: processos de governança num litoral em risco. Ambiente \& Sociedade, 15(1), 23-40. doi.org/10.1590/S1414753X2012000100003

SedNet, 2004. Contaminated sediments in European river basins. Co-ordinator Jos Brils, TNO, The Netherlands. Editors, Wim Salomons, Jos Brils, SedNet contractors, SedNet Stakeholders Panel, SedNet participants

SedNet, 2006. Sediment management- an essential element of River Basin Management Plans, Report on the SedNet round table discussion, Venice.

Sheehan, C., Harrington, J.R., Murphy, J.P, 2008. An investigation into potential beneficial uses of dredged material in Ireland CIT.

Sheehan, C., Harrington, J., Murphy, J.D., 2010. An Environmental and Economic Assessment of Topsoil Production from Dredge Material. Journal of Resources, Conservation \& $\begin{array}{lll}\text { Recycling } & 55, & 209\end{array}$ doi.org/10.1016/j.resconrec.2010.09.011

Shields, Y., O’ Connor, J., O’ Leary, J., 2005, Ireland's Ocean Economy \& Resources. Marine Institute, Marine Foresight Series No 4, December 2005.

Siham, K., Fabrice, B., Edine, A.N., Patrick, D., 2008. Marine dredged sediments as new materials resource for road construction. Waste Management 28 (5), 919-928. doi.org/10.1016/j.wasman.2007.03.027

Silva, P.A., 2011. Impactos da Exploração de Inertes na Plataforma Continental. In: Coelho, C., Silva, P.A. da, Pinheiro, L.A., Gonçalves, D.S., 2011 (eds.), Dragagens: Fundamentos,
Técnicas e Impactos, Universidade de Aveiro, Aveiro, Portugal, pp. 11-64.

Soares, H.M., Boaventura, R.A.R., Esteves da Silva, J., 1999. Sediments as monitors of heavy metal contamination in the Ave River Basin (Portugal): multivariate analysis of data. Environmental Pollution 105, 311-323.

Sutherland, R.A., Tolosa, C.A., Tack, F.M.G., Verloo, M.G., 2000. Characterization of selected element concentration and enrichment ratios in background and anthropogenically impacted roadside areas. Archives of Environmental Contamination and Toxicology 38, 428-438. doi.org/10.1007/s002440010057

Tchounwou, P.B., Yedjou, C.G., Patlolla, A.K., Sutton, D.J., 2012. Heavy metals toxicity and the environment. EXS. 101. 133164. doi:10.1007/978-3-7643-8340-4_6

Tessier, A., Campbell, P.G.C., Bisson, M., 1979. Sequential extraction procedure for the speciation of particulate trace metals. Analytical Chemistry 51, 844-851. doi: 10.1021/ac50043a017

Tomlinson, D.L., Wilson, J.G., Harris, C.R., Jeffrey, D.W., 1980. Problems in the assessment of heavy metal levels in estuaries and the formation of pollution index. Helgolander Meeresuntersuchugen 33, 566-575. doi:10.1007/BF02414780

Turekian, K.K., Wedepohl, K.H., 1961. Distribution of the elements in some major units of the earth's crust. American Geology Society Bulletin 72, 175-182. Doi 10.1130/00167606(1961)72[175:DOTEIS]2.0.CO;2

van Maren, D.S., Cronin, K., 2015. The impact of channel deepening and dredging on estuarine sediment concentration. Continental Shelf Research 95, 1-14. doi.org/10.1016/ j.csr.2014.12.010

Vaz, N., Dias, J.M., Leitão, P.C., 2009. Three-dimensional modelling of a tidal channel: the Espinheiro Channel (Portugal). Continental Shelf Research 29, 29-41. doi.org/10.1016/j.csr.2007.12.005

Velosa, A., Cachim, P., 2011. Utilização de Dragados em Materiais de Construção. In: Coelho, C., Silva, P.A. da, Pinheiro, L.A., Gonçalves, D.S., 2011 (eds.), Dragagens: Fundamentos, Técnicas e Impactos, Universidade de Aveiro, Portugal, 241-255.

Veloso-Gomes, F., Barroca, A., Ramos Pereira, A., Sousa Ramos, C., Calado, H., Gomes Ferreira, J., Biscoito, M., 2007. A gestão da zona costeira Portuguesa. Revista da Gestão Costeira Integrada, 7(2), 13.

Verfaillie, E., Du Four, I., Van Lancker, V., Maes, F., and Schrijvers, J. (2005). Dredging and disposal of dredged material. Towards a Spatial Structure Plan for Sustainable Management of the Sea: Mixed Actions-Final Report: SPSD II (MA/02/006), p. 150-162.

Vital, H. and Stattegger, K., 2000. Sediment Dynamics in the Lowermost Amazon. Journal of Coastal Research, 16, 316-328.

Wang, X.H., Andutta, F.P., 2013. In: Manning, A.J. (ed.), Sediment transport dynamics in ports, estuaries and other coastal environments. Earth and Planetary Sciences, Sediment Transport Processes and Their Modelling Applications. doi: 10.5772/51022

Warwick, R.M., Goss-Custard, J.D., Kirby, R., George, C.L., Pope, N.D., Rowden, A.A., 1991. Static and dynamic environmental factors determining the community structure of estuarine macrobenthos in SW Britain: Why is the severn estuary different? Journal of Applied Ecology 28 (1), 329-345. doi: $10.2307 / 2404133$ 
Yokel, R.A., Lasley, S.M., Dorman, D.C., 2006 The speciation of metals in mammals influences their toxicokinetics and toxicodynamics and therefore human health risk assessment. Journal of Toxicology and Environmental Health, Part B, 9(1), 63-85. doi: 10.1080/15287390500196230

Zaaboub, N., Helali, M.A., Martins, M.V., Ennouri, R., Béjaoui, B., da Silva, E.F., El Bour, M., Aleya, L., 2016. Assessing pollution in a Mediterranean lagoon using acid volatile sulfides and estimations of simultaneously extracted metals. Environmental
Science and Pollution Research, 23, 21908-21919. doi:10.1007/s11356-016-7431-5

Zaaboub, N., Martins, M.V.A., Bejaoui, A.D.B., Galgani, F., El Bour, M., Aleya, L., 2015. Accumulation of trace metals in sediments in a Mediterranean Lagoon: usefulness of metal sediment fractionation and elutriate toxicity assessment. Environmental Pollution 207, 226-237. doi.org/10.1016 /j.envpol.2015.09. 